International Journal of Environmental Research and

Article

\title{
Temporal Variations in Physico-Chemical and Microbiological Characteristics of Mvudi River, South Africa
}

\author{
Joshua N. Edokpayi ${ }^{1}{ }^{1}$, John O. Odiyo ${ }^{1}$, Titus A.M. Msagati ${ }^{2}$ and Natasha Potgieter ${ }^{3}$ \\ 1 Department of Hydrology and Water Resources, University of Venda, Private Bag X5050, \\ Thohoyandou 0950, South Africa; E-Mail: john.odiyo@univen.ac.za \\ 2 College of Science, Engineering and Technology, Nanotechnology and Water Sustainability \\ Research Unit, Florida Science Campus, University of South Africa, Roodepoort 1709, \\ Johannesburg, South Africa; E-Mail: msagatam@unisa.ac.za \\ 3 Department of Microbiology, University of Venda, Private Bag X5050, Thohoyandou 0950, \\ South Africa; E-Mail: natasha.potgieter@univen.ac.za
}

* Author to whom correspondence should be addressed; E-Mail: joshua.edokpayi@ univen.ac.za; Tel.: +27-015-962-8065.

Academic Editor: Miklas Scholz

Received: 14 March 2015 / Accepted: 9 April 2015 / Published: 14 April 2015

\begin{abstract}
Surface water has been a source of domestic water due to shortage of potable water in most rural areas. This study was carried out to evaluate the level of contamination of Mvudi River in South Africa by measuring turbidity, electrical conductivity (EC), $\mathrm{pH}$, concentrations of nitrate, fluoride, chloride, and sulphate. E. coli and Enterococci were analysed using membrane filtration technique. Average $\mathrm{pH}, \mathrm{EC}$ and Turbidity values were in the range of $7.2-7.7,10.5-16.1 \mathrm{mS} / \mathrm{m}$ and $1.3-437.5$ NTU, respectively. The mean concentrations of fluoride, chloride, nitrate and sulphate for both the wet and the dry seasons were $0.11 \mathrm{mg} / \mathrm{L}$ and $0.27 \mathrm{mg} / \mathrm{L}, 9.35 \mathrm{mg} / \mathrm{L}$ and $14.82 \mathrm{mg} / \mathrm{L}, 3.25 \mathrm{mg} / \mathrm{L}$ and $6.87 \mathrm{mg} / \mathrm{L}, 3.24 \mathrm{mg} / \mathrm{L}$ and $0.70 \mathrm{mg} / \mathrm{L}$, respectively. E. coli and Enterococci counts for both the wet and the dry seasons were $4.81 \times 10^{3}(\log =3.68)$ and $5.22 \times 10^{3}(\log =3.72)$, $3.4 \times 10^{3}(\log =3.53)$ and $1.22 \times 10^{3}(\log =3.09)$, per $100 \mathrm{~mL}$ of water, respectively. The count of $E$. coli for both seasons did not vary significantly $(p>0.05)$ but Enterococci count varied significantly $(p<0.001)$. All the physico-chemical parameters obtained were within the recommended guidelines of the Department of Water Affairs and Forestry of South Africa and the World Health Organization for domestic and recreational water use for both
\end{abstract}


seasons except turbidity and nitrates. The microbiological parameters exceeded the established guidelines. Mvudi River is contaminated with faecal organisms and should not be used for domestic purposes without proper treatment so as to mitigate the threat it poses to public health.

Keywords: E. coli; Enterococci; public health; water quality; wet and dry seasons

\section{Introduction}

Water is necessary for healthy living and must be available to consumers in sufficient quantity and at high quality [1]. In developing countries of the world, most rural communities depend on water from wells, ponds, springs and rivers for their domestic needs [2,3]. This is largely due to either the lack of access to or inability to afford the price of potable water [4]. About 1.1 billion people in the world lack basic access to clean, safe and adequate water resources and $85 \%$ of them live in rural areas [5]. According to Schaefer [6], $80 \%$ of illnesses and deaths in developing countries are due to the use of water of poor quality.

The Council for Scientific and Industrial Research (CSIR) reported that almost 2.11 million people in South Africa lack access to any safe water infrastructure [7]. Population growth coupled with increased industrialisation, livestock farming and urbanisation have led to frequent contamination of river systems. This is further exacerbated by the lack of adequate sanitation facilities in rural areas resulting in faecal contamination of surface water with its attendant negative effects on human health and the environment $[8,9]$. Contamination of river systems by point and non-point sources of pollution degrades water quality and affects its use for domestic, agricultural, recreational and aesthetic purposes [10]. Microbial contamination of water is a major threat to public health as water associated diseases comprise about $9.1 \%$ of global disease burden $[11,12]$. Contaminated water endangers both the physical and social wellbeing of all people and it is an offense to human dignity [13]. Drinking and use of faecally contaminated water has far reaching negative health effects such as cholera, diarrhoea, ring worm infestation and schitosomiasis, among others [5,14].

CSIR [7] reported that diarrhoea is the third South African's biggest killer disease, which is not only restricted to children and immune compromised individuals but also among adults between the ages of 45-65 years. A record of an annual death of 1.6 million people is caused by the use of unsafe water and lack of access to basic sanitation and $90 \%$ of the victims are children under the age of 5 from developing countries [5]. Most river systems in urban areas are monitored constantly for their microbiological quality but there are limited data on the microbiological quality of rivers in rural communities, which are more prone to contamination. This study was carried out to assess the physico-chemical and microbiological quality of Mvudi River, which is used by residents surrounding it for domestic, recreational and agricultural purposes. 


\section{Experimental Section}

\subsection{Study Area}

Figure 1 shows the study area which is located on geographical coordinates E030 $27^{\prime} 59.3^{\prime \prime}$ and E030 $28^{\prime} 46.0^{\prime \prime}$ latitude and S22 59'37.5' and S23 $03^{\prime} 10.4^{\prime \prime}$ longitude and falls within the summer climatic condition of South Africa with an average rainfall in the range of 400 to $800 \mathrm{~mm}$ annually. Major land uses include informal and formal settlements, subsistence and commercial agriculture, waste disposal sites and wastewater treatment plant. This region is characterized by a warm wet season which is associated with high temperatures up to $40{ }^{\circ} \mathrm{C}$ usually between October and March, with peak precipitation in January and February. The cool dry season has a temperature range between $12{ }^{\circ} \mathrm{C}$ and $22{ }^{\circ} \mathrm{C}$ and begins from April to September [15].

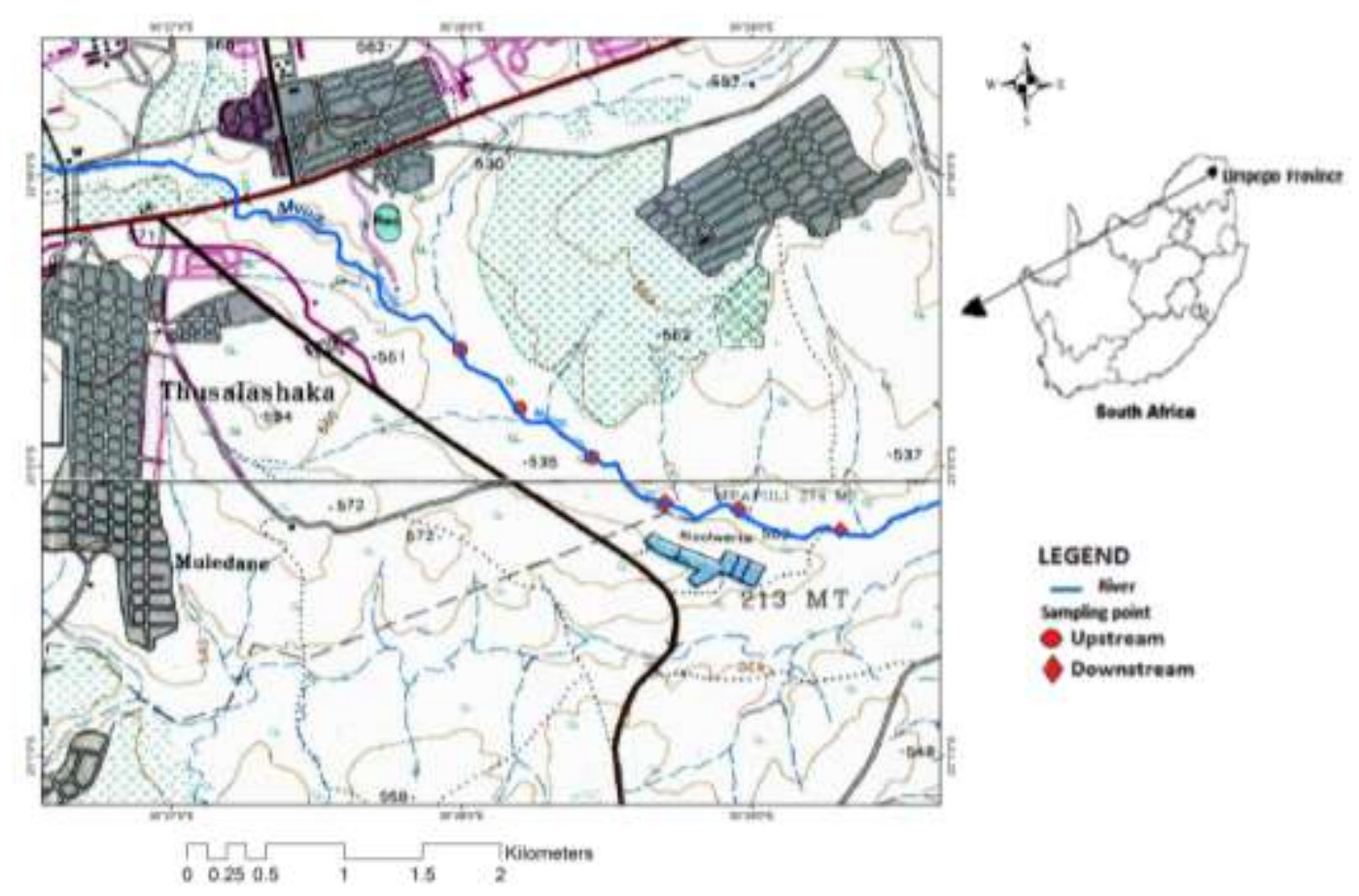

Figure 1. Map of the study area.

\subsection{Sampling}

Water samples were randomly collected from six points along the Mvudi River using the Direct Sampling method. The sampling was done from January to June 2014. Polypropylene sampling bottles were used for sample collection; they were rinsed with the samples prior to collection from the river. Field measurements of $\mathrm{pH}$ and electrical conductivity (EC) were performed using a $\mathrm{pH}$ and EC multimeter and turbidity was measured with a turbidimeter. The instruments were calibrated according to the manufacturer guidelines. The samples were transported on ice-chest in a cooler box to Microbiology Laboratory of the University of Venda. The samples for microbial analysis were analysed within $6 \mathrm{~h}$ of collection except January samples, which were analysed within $16 \mathrm{~h}$ of collection. 


\subsection{Analysis of Microbiological Parameters}

E. coli and Enterococci counts were analysed in each sample with the protocol proposed by the American Public Health Agency [16]. Briefly, sample aliquots of $100 \mathrm{~mL}$ were filtered using a $0.45 \mu \mathrm{m}$ pore size, $47 \mathrm{~mm}$ diameter Millipore filter membrane. E.coli and Enterococci bacteria were enumerated at $37^{\circ} \mathrm{C}$ on mFC (Acumedia, Pretoria, South Africa) and mEnterococcus agar (Acumedia) plates after 24 and $48 \mathrm{~h}$ incubation, respectively. The samples were analysed in duplicate and recorded as colony forming unit per $100 \mathrm{~mL}$.

\subsection{Anion Analysis}

The samples were filtered through 0.45 micron syringe filter and placed in an autosampler connected to an 850 IC professional Ion Chromatograph (Metrohm (pty) Ltd, Pretoria, South Africa). Calibration standards were prepared from multi-element standards of fluoride, chloride, nitrate and sulphate. $1 \mathrm{mg} / \mathrm{L}, 5 \mathrm{mg} / \mathrm{L}, 10 \mathrm{mg} / \mathrm{L}$ and $20 \mathrm{mg} / \mathrm{L}$ were prepared by serial dilution from a stock solution of $100 \mathrm{mg} / \mathrm{L}$. The eluent used was a combination of sodium carbonate $\left(\mathrm{Na}_{2} \mathrm{CO}_{3}\right)$ and sodium bicarbonate $\left(\mathrm{NaHCO}_{3}\right)$; prepared by weighing accurately $0.1680 \mathrm{~g}$ and $0.6784 \mathrm{~g}$ into $2 \mathrm{~L}$ volumetric flask and filled to the mark using ultrapure water $(18.2 \mathrm{M} \Omega)$. The eluent was degassed before introduction to the IC system. A sample loop of $20 \mu \mathrm{L}, 50 \mathrm{mmol} / \mathrm{L}$ of sulfuric acid as the suppressor solution flowing at a rate of $0.5 \mathrm{~mL} / \mathrm{min}$ was employed. The IC has a flow rate of $0.7 \mathrm{~mL} / \mathrm{min}$, maximum and minimum pressure of $15.0 \mathrm{mPa}$ and $0.1 \mathrm{mPa}$, respectively. The samples were analysed in triplicate.

\subsection{Validation of Analytical Methodology}

In order to validate the analytical methodology, recovery studies were performed. Known concentrations of the test analyte were added to the sample. The concentrations of both the spiked and unspiked samples were determined and percentage recovery was obtained.

\subsection{Statistical Analyses}

Data analyses were performed using Microsoft Excel and SPSS 20.0 statistical software.

\section{Results and Discussion}

\subsection{Physico-chemical Parameters}

The $\mathrm{pH}$ values of the river over the study period were in the range of 6.7-8.0. Table 1 shows the average $\mathrm{pH}$ values for each of the sampling month. The average $\mathrm{pH}$ values of the dry season (April-June) (7.5) was slightly higher than that obtained for the wet season (January-March) (7.4) and fell within the recommended limit of 6-9 set by the Department of Water Affairs and Forestry of South Africa (DWAF) [17] and the World Health organization (WHO) [18] for domestic, recreational and agricultural water use. There is no significant difference in the means of the $\mathrm{pH}$ values observed for both the wet and the dry seasons $(p>0.05)$. 
Table 1. Average levels of physico-chemical parameters in Mvudi River.

\begin{tabular}{cccc}
\hline Months & $\mathbf{p H}$ & Turbidity $(\mathbf{N T U})$ & EC $(\mathbf{m S} / \mathbf{m})$ \\
\hline January & $7.4 \pm 0.04$ & $429 \pm 31$ & $10.5 \pm 0.08$ \\
February & $7.3 \pm 0.04$ & $20.4 \pm 4.3$ & $15.9 \pm 0.66$ \\
March & $7.7 \pm 0.16$ & $17.6 \pm 8.2$ & $13.6 \pm 1.8$ \\
April & $7.2 \pm 0.22$ & $8.0 \pm 0.67$ & $12.8 \pm 0.62$ \\
May & $7.6 \pm 0.05$ & $7.8 \pm 3.5$ & $16.1 \pm 2.13$ \\
June & $7.6 \pm 0.05$ & $1.9 \pm 1.16$ & $13.8 \pm 1.67$ \\
DWAF guidelines & $6-9$ & $<0.1$ & $<70$ \\
WHO guidelines & $6.5-9.5$ & $<0.1$ & 600 \\
\hline
\end{tabular}

$\mathrm{pH}$ plays an important role in the speciation and bioavailability of metals in aquatic environment. A $\mathrm{pH}<4$ will increase the toxicity and bioavailability of most heavy metals while a $\mathrm{pH}>9$ will influence the toxicity of ammonium ion. The $\mathrm{pH}$ values obtained in this study in the dry and the wet seasons are comparable to those reported by Singh et al. [19]. Wilbers et al. [20] reported a slightly lower $\mathrm{pH}$ in the wet season than in the dry season in their studies of spatial and temporal variability of surface water pollution in the Mekong Delta, Vietnam.

Electrical conductivity of rivers is a function of the geology of the area. The EC trend in rivers that flow predominantly across granite rocks which contain no ionisable metals will be generally lower than those that flow across rocks that contain ionisable metals which are readily leached into the river [21]. From Table 1, the EC values obtained were different in each sampling month. The lowest EC value was obtained in January and the highest in May. This result was unexpected as the wet season which is characterized with heavy rainfall is supposed to be accompanied with high EC values due to high surface runoff from agricultural lands and roads as reported by Shabalala et al. [21] and Anhwange et al. [22].

A similar result to the findings from this study was reported by Vaishali et al. [23]. The EC determined is in the same range in both seasons and statistical analysis of the data obtained for both seasons showed no significant difference $(p>0.05)$. The value of EC usually gives an indication of the presence of dissolved ions in water [24] and the presence of these ions can alter the taste of water and also contribute to the hardness of water. It also gives an indication of the total dissolved solids present in the water. Water with high EC values is not suitable for domestic purposes and irrigation as it can lead to the salinity of agricultural soils. The obtained values were within the guideline value of DWAF (70 mS/m) [17] and WHO (600 mS/m) [18].

The turbidity values obtained decreased as expected from January to June. The values were in the range of 13.3-473 NTU in the wet season and 1.3-14.7 NTU in the dry season. The high turbidity values obtained during the wet season can be attributed to high incidences of rainfall, which lead to increased erosion and surface runoff carrying a lot of suspended materials into the river. High turbidity values indicate the possible presence of micro-organisms, clays, silts and other suspended solids in water, which affect its aesthetic value by causing it to appear cloudy [25].

Turbidity is usually associated with reduced penetration of light rays which can adversely affect benthic organisms. The low values of turbidity in the dry season could be due to reduced circulation velocity of water, causing the suspended particles to settle down in sediment [22]. The turbidity values 
obtained in both seasons exceeded the DWAF and WHO guidelines of $<1$ NTU for domestic water use [17]. Statistical treatment of the data showed a significant difference $(p<0.006)$ for both the wet and the dry seasons. Seasonal variation in turbidity levels were recorded by Lin et al. [26] and Fatoki et al. [27] on their investigation of Umgeni and Umtaka Rivers in KwaZulu Natal and Eastern Cape Provinces of South Africa, respectively.

\subsection{Anions}

The validation test performed on the analytical methods employed gave reproducible results with acceptable recoveries. Recovery percentages were $92.5 \%$ for fluoride, $95.7 \%$ for chloride, $95.1 \%$ for nitrate and $97.3 \%$ for sulphate. The results obtained are presented in Table 2 . The highest fluoride $\left(\mathrm{F}^{-}\right)$ concentration $(0.150 \pm 0.05 \mathrm{mg} / \mathrm{L})$ was obtained in March and the lowest in January $(0.058 \mathrm{mg} / \mathrm{L})$ (Table 2). The mean concentration of $\mathrm{F}^{-}$for the wet and the dry seasons were $0.11 \mathrm{mg} / \mathrm{L}$ and $0.27 \mathrm{mg} / \mathrm{L}$, respectively. The low $\mathrm{F}^{-}$concentration in the wet season could be due to dilution as a result of heavy rains. $p$-Value of 0.428 was obtained which shows that the mean difference for both wet and the dry seasons did not vary significantly. The concentrations obtained for both seasons were within the limit of $1 \mathrm{mg} / \mathrm{L}$ and $1.5 \mathrm{mg} / \mathrm{L}$ set by DWAF [17] and WHO [18] for domestic water use. This result is comparable to those obtained by Lalaury and Gopmath [28]. Ravindra et al. [29] reported a slightly higher concentration of fluoride in the wet season than in the dry season. Low $\mathrm{F}^{-}$concentration is beneficial to man as it aids the calcification of dental enamel, but when the concentration exceeds $1 \mathrm{mg} / \mathrm{L}$, it can cause dental and skeletal fluorosis which can be severe at higher concentrations [28].

Table 2. Average monthly concentrations of anions in Mvudi River.

\begin{tabular}{|c|c|c|c|c|c|c|}
\hline \multirow{2}{*}{$\begin{array}{c}\text { Anions } \\
(\mathrm{mg} / \mathrm{L})\end{array}$} & \multicolumn{6}{|c|}{ Sampling Months } \\
\hline & January & February & March & April & May & June \\
\hline Fluoride & $0.058 \pm 0.01$ & $0.106 \pm 0.01$ & $0.15 \pm 0.05$ & $0.064 \pm 0.04$ & $0.105 \pm 0.06$ & $0.105 \pm 0.06$ \\
\hline Chloride & $5.59 \pm 0.31$ & $8.90 \pm 1.27$ & $13.56 \pm 9.53$ & $9.27 \pm 0.14$ & $15.75 \pm 6.21$ & $19.48 \pm 12.0$ \\
\hline Nitrate & $5.25 \pm 4.72$ & $1.97 \pm 0.52$ & $2.53 \pm 1.37$ & $4.86 \pm 3.88$ & $7.75 \pm 5.86$ & $8.17 \pm 5.52$ \\
\hline Sulphate & $2.79 \pm 2.1$ & $1.89 \pm 0.63$ & $5.04 \pm 3.36$ & $0.66 \pm 0.07$ & $0.74 \pm 0.15$ & $0.76 \pm 0.15$ \\
\hline
\end{tabular}

The average concentration of chloride $\left(\mathrm{Cl}^{-}\right)$increased from $5.59 \pm 0.31 \mathrm{mg} / \mathrm{L}$ in January to $8.90 \pm 1.27 \mathrm{mg} / \mathrm{L}$ in February and to $13.56 \pm 9.53 \mathrm{mg} / \mathrm{L}$ in March; a decrease to $9.27 \pm 0.14 \mathrm{mg} / \mathrm{L}$ was observed in April but an increase was observed again in May $(15.72 \pm 6.21 \mathrm{mg} / \mathrm{L})$ and June $(19.48 \pm 12.08 \mathrm{mg} / \mathrm{L})$. The $\mathrm{Cl}^{-}$concentrations were higher in the dry season than in the wet season. This could possibly be due to high dilution of chloride as a result of high rainfall in the wet season. The difference in the means for the wet and the dry seasons was statistically different $(p<0.015)$. The concentrations obtained fell within the set guidelines of DWAF (100 mg/L) [17] and WHO $(250 \mathrm{mg} / \mathrm{L})[18]$. These low concentrations agree with the low level of electrical conductivity observed for both seasons.

The average nitrate concentration varied between $4.68 \pm 3.88 \mathrm{mg} / \mathrm{L}, 7.75 \pm 5.86 \mathrm{mg} / \mathrm{L}$ and $8.17 \pm 5.22 \mathrm{mg} / \mathrm{L}$ in the months of April, May and June, respectively; while $5.25 \pm 4.72 \mathrm{mg} / \mathrm{L}$, $1.97 \pm 0.52 \mathrm{mg} / \mathrm{L}$ and $2.53 \pm 1.37 \mathrm{mg} / \mathrm{L}$ values were recorded for January, February and March, respectively. The average nitrate $\left(\mathrm{NO}_{3}{ }^{-}\right)$concentration was higher in the dry season than in the wet 
season. A similar observation was reported by Anhwange et al. [22], Adeyemo et al. [30] and Shrestha and Kazava [31]. The concentrations of $\mathrm{NO}_{3}{ }^{-}$are usually built up during the dry season while in the wet season there is high dilution due to high rainfall events. These are the possible reasons for the slightly higher concentration of nitrate observed in the dry season [30].

The concentrations of $\mathrm{NO}_{3}{ }^{-}$did not exceed the DWAF and WHO threshold limits for domestic water use but the concentration determined can induce eutrouphication. Nitrate concentration in the range of $2.5-10 \mathrm{mg} / \mathrm{L}$ can render a water body eutrouphic and consequently lead to the blossoming of algae, some of which are poisonous [17,21]. A significant difference in the mean values of the concentrations was observed $(p<0.035)$ for the wet and the dry seasons. High nitrate concentrations in water usually lead to eutrouphication with its consequences and nitrate concentration exceeding $23 \mathrm{mg} / \mathrm{L}$ has been linked to methaemoglobinaemia condition in children [17].

Very low concentrations of sulphate $\left(\mathrm{SO}_{4}{ }^{2-}\right)$ were observed during the sampling months. The highest $\mathrm{SO}_{4}{ }^{2-}$ concentrations were observed in March $(5.04 \pm 3.36 \mathrm{mg} / \mathrm{L})$, January $(2.79 \pm 2.1 \mathrm{mg} / \mathrm{L})$ and February $(1.89 \pm 0.63 \mathrm{mg} / \mathrm{L})$ all in the wet season as shown in Table 2 . This could be attributed to high surface runoffs from roads carrying sulphate minerals into the river. Ravindra et al. [29] in their studies of seasonal variations in physico-chemical characteristics of River Yamuna reported a higher sulphate concentration in the wet season than in the dry season. The concentrations in the dry season were in the range $0.66-0.74 \mathrm{mg} / \mathrm{L}$. The $\mathrm{SO}_{4}{ }^{2-}$ concentrations for both seasons were within the guidelines of DWAF [17] and WHO for domestic water use [18] of $200 \mathrm{mg} / \mathrm{L}$ and $250 \mathrm{mg} / \mathrm{L}$, respectively. The mean difference for both seasons varied significantly $(p<0.005)$.

Correlation studies were performed on the concentrations of the anions during the sampling period. Fluoride showed a significant correlation with chloride $(\mathrm{r}=0.382, p<0.05)$, nitrate also showed a positive and significant correlation with chloride $(r=0.457, p<0.01)$. Sulphate did not correlate significantly with any of the other anions. Table 3 shows the average concentrations of the anions upstream and downstream of the river. Generally, higher concentrations were observed downstream than upstream of the river. This could be attributed to various land use activities such as agricultural, small scale industries and wastewater treatment works located along the river from upstream to downstream which can result to higher concentrations of pollutants downstream [32].

Table 3. Average anion concentrations upstream (Us) and downstream (Ds) of Mvudi River.

\begin{tabular}{|c|c|c|c|c|c|c|c|}
\hline \multirow{2}{*}{\multicolumn{2}{|c|}{$\begin{array}{l}\text { Anions } \\
(\mathrm{mg} / \mathrm{L})\end{array}$}} & \multicolumn{6}{|c|}{ Sampling Months } \\
\hline & & January & February & March & April & May & June \\
\hline \multirow[t]{2}{*}{ Fluoride } & Us & $0.052 \pm 0.01$ & $0.098 \pm 0.01$ & $0.131 \pm 0.0$ & $0.056 \pm 0.04$ & $0.068 \pm 0.09$ & $0.069 \pm 0.08$ \\
\hline & Ds & $0.06 \pm 0.01$ & $0.110 \pm 0.01$ & $0.159 \pm 0.06$ & $0.068 \pm 0.04$ & $0.130 \pm 0.06$ & $0.113 \pm 0.05$ \\
\hline \multirow[t]{2}{*}{ Chloride } & Us & $5.32 \pm 0.29$ & $7.33 \pm 0.18$ & $9.93 \pm 2.97$ & $9.15 \pm 0.66$ & $12.13 \pm 3.15$ & $12.79 \pm 2.95$ \\
\hline & Ds & $5.73 \pm 0.23$ & $9.68 \pm 0.64$ & $15.37 \pm 11.64$ & $9.33 \pm 0.12$ & $12.31 \pm 6.95$ & $22.79 \pm 13.98$ \\
\hline \multirow[t]{2}{*}{ Nitrate } & Us & $4.75 \pm 5.92$ & $1.43 \pm 0.01$ & $3.07 \pm 1.39$ & $2.06 \pm 0.85$ & $9.36 \pm 11.46$ & $5.21 \pm 1.53$ \\
\hline & Ds & $7.03 \pm 6.94$ & $2.38 \pm 0.40$ & $3.01 \pm 1.49$ & $6.95 \pm 4.24$ & $9.16 \pm 3.30$ & $12.56 \pm 6.43$ \\
\hline \multicolumn{2}{|c|}{ Sulphate Us } & $1.52 \pm 0.01$ & $1.14 \pm 0.33$ & $2.29 \pm 0.30$ & $0.641 \pm 0.05$ & $0.695 \pm 0.13$ & $0.834 \pm 0.21$ \\
\hline & Ds & $3.35 \pm 2.49$ & $2.26 \pm 0.27$ & $6.29 \pm 3.36$ & $1.34 \pm 0.09$ & $0.767 \pm 0.16$ & $0.654 \pm 0.09$ \\
\hline
\end{tabular}




\subsection{Microbiological Parameters}

Faecal contamination is of global concern owing to the negative health risks associated with it. Figures 2 and 3 show the average counts of E. coli and Enterococci observed in this study. The highest count of E. coli was observed in March in the wet season $(\log =4.06)$ followed by April in the dry season $(\log =3.95)$. The mean count of $E$. coli recorded for the wet and the dry seasons were $4.81 \times 10^{3}(\log =3.86)$ and $5.22 \times 10^{3}(\log =3.72)$, respectively. The average count of $E$. coli was slightly higher in the dry season when compared with the wet season. These levels exceeded the DWAF and WHO recommended guidelines for domestic and recreational use of water $[17,18]$.

Abstraction of water from Mvudi River is thus regarded a risk to the health of people that use the water for various purposes. The counts obtained were not statistically different $(p>0.05)$ for both seasons.

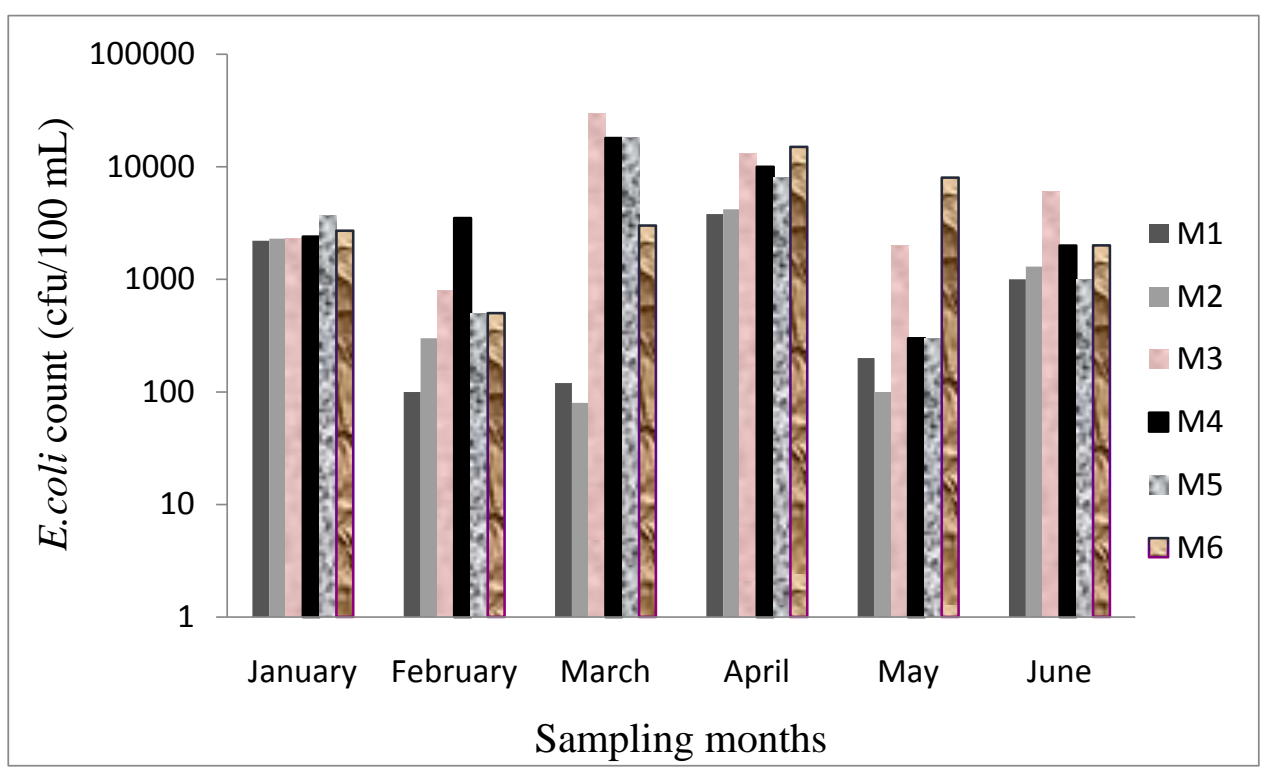

Figure 2. E.coli count in each sampling site of Mvudi River.

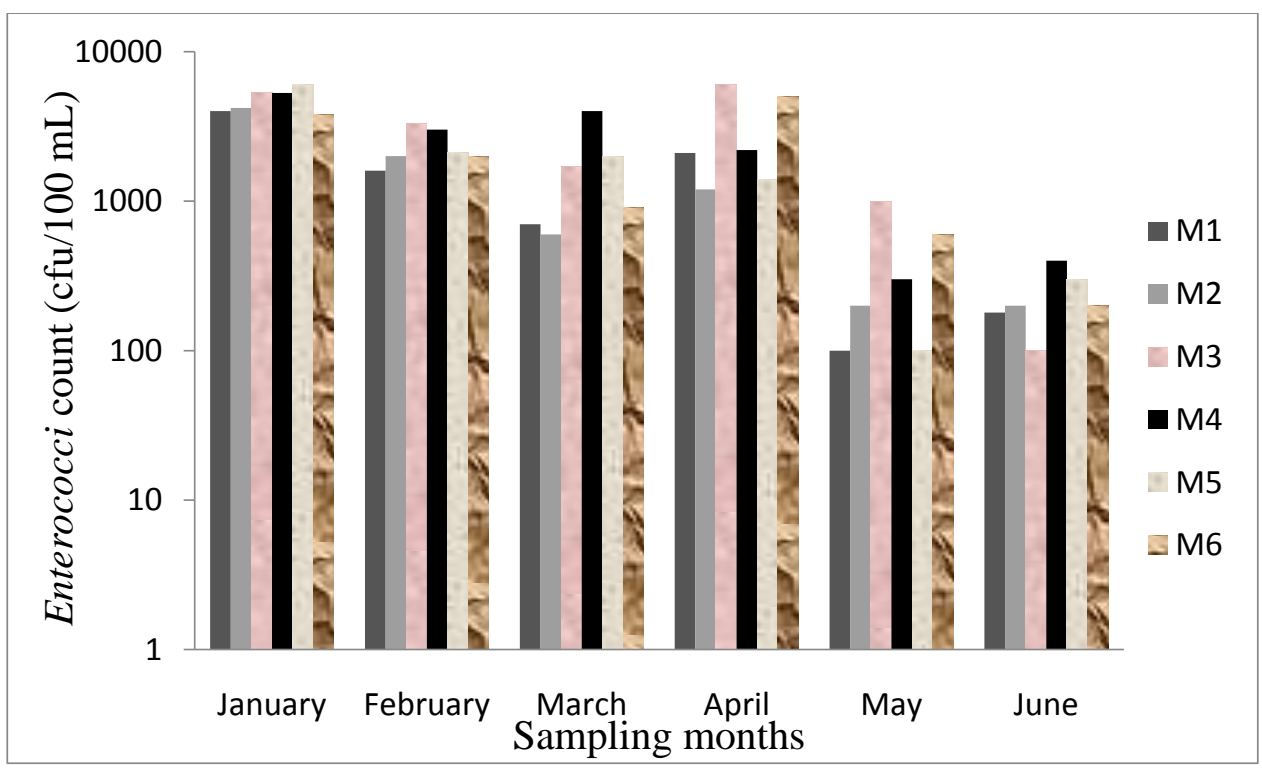

Figure 3. Enterococci count in each sampling site of Mvudi River. 
Enterococci count varied differently in each of the sampling months; it decreased from $5.23 \times 10^{3}$ $(\log =3.73)$ in January to $3.33 \times 10^{3}(\log =3.52)$ in February and a further decrease was observed in March (log = 322). An increase was observed in April $(\log =3.47)$ and a sharp decrease was again recorded in May $(\log =2.58)$ and June $(\log =2.48)$. The levels obtained were higher in the wet season than in the dry season. Differences in the means for both seasons were significantly different $(p<0.001)$. The downstream of the river recorded higher counts of E. coli and Enterococci as shown in Figures 3 and 4 than the upstream. The data for both seasons exceeded the recommended guidelines set by DWAF and WHO for water use [17,18].

Seasonal variations had influence on the levels of faecal bacteria thereby making it very difficult to predict their value at any given time. Bacterial counts are usually expected to be higher during the wet season because of high rainfall events and are more prevalent in turbid water [33] but high ultra violet radiation from sunlight can reduce the bacterial counts in the rainy season which is associated with high sunshine in Limpopo Province of South Africa. Enterococci count was higher in the wet season than in the dry season which was opposite to E. coli count which was higher in the dry season than in the wet season. The high levels of both indicator organisms found in this study is of a great concern as it can negatively affect the health of the users of this resource. Various seasonal patterns of feacal indicator organisms have been reported for several rivers in South Africa. Chigor et al. [34] and Lin et al. [25] did not observe any significant differences in the counts of faecal indicator organisms for both the wet and dry seasons on Buffalo and Umgeni Rivers in South Africa. Fatoki et al. [27] observed a higher count of faecal indicator organisms in the rainy season than in the dry season while, Sibanda et al. [35] reported a higher count of faecal indicator organisms in Dryini sampling point during the dry season than in the wet season in their studies on Tyume River in Eastern Cape Province in South Africa. Figures 4 and 5 show the average counts of E. coli and Enterococci on the upstream and downstream of the river.

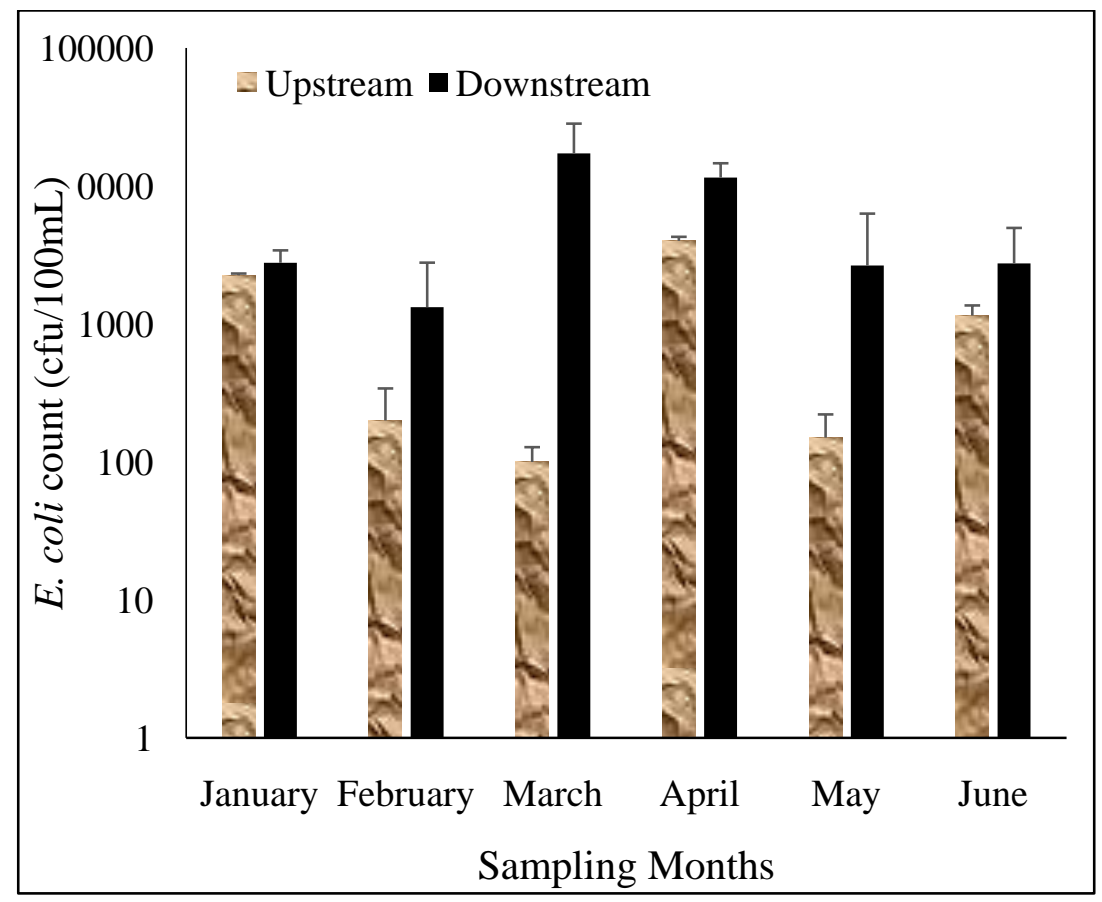

Figure 4. E. coli count in the upstream and downstream of Mvudi River. 


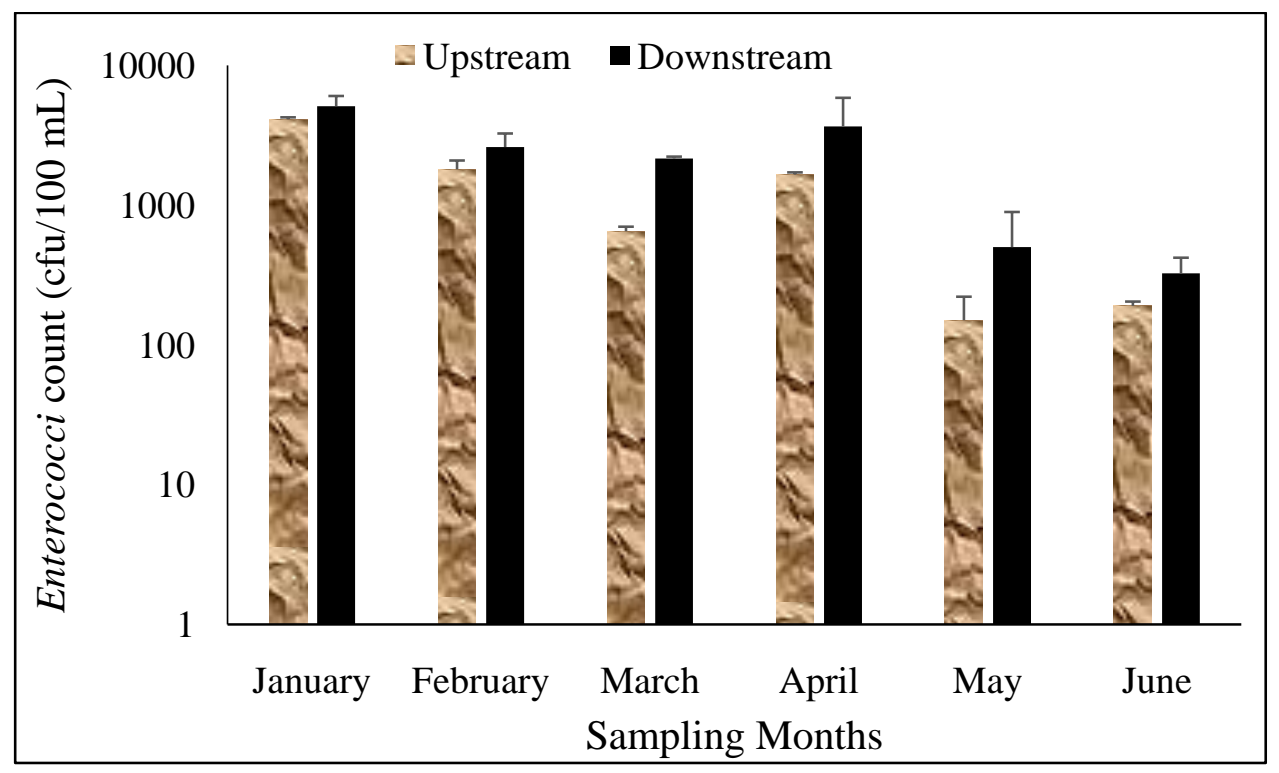

Figure 5. Enterococci count in the upstream and downstream of Mvudi River.

Generally, the levels of faecal indicator organisms were higher downstream than upstream of the river and can be attributed to various anthropogenic activities occurring along the river and could also be due to effluents from wastewater treatment works.

\section{Conclusions}

From the experimental observation, the physico-chemical parameters were within the set guidelines of DWAF and WHO for domestic water use except for turbidity. The microbiological parameters exceeded the guideline values of $0 \mathrm{cfu} / 100 \mathrm{~mL}, 30 \mathrm{cfu} / 100 \mathrm{~mL}$, and $\leq 1000 \mathrm{cfu} / 100 \mathrm{~mL}$ for domestic, recreational and irrigation water use [36,37]. $\mathrm{pH}, \mathrm{EC}$ and the concentrations of $\mathrm{F}^{-}$and $E$. coli count did not vary significantly for both the wet and the dry seasons. Turbidity values, the concentrations of $\mathrm{NO}_{3}{ }^{-}, \mathrm{Cl}^{-}, \mathrm{SO}_{4}{ }^{2-}$, and Enterococci count varied significantly for both seasons. Generally, the downstream of the river was more contaminated than the upstream. It is recommended that the water should be properly disinfected before any use. Measures should be put in place to discourage abstraction of water from this river in order to protect the health of the communities that rely on it for domestic, agricultural and recreational purposes.

\section{Acknowledgments}

The authors wish to acknowledge the Research and Publication Committee (RPC) of the University of Venda for financially supporting this research under the project grant number S357.

\section{Author Contributions}

Joshua N. Edokpayi, John O. Odiyo, Titus A.M. Msagati and Natasha Potgieter planned and designed the research. Joshua N. Edokpayi carried out the collection and analyses of the samples and wrote the first draft of the manuscript. John. O. Odiyo, Titus A.M. Msagati and Natasha Potgieter 
contributed to the writing and discussion of the final manuscript. All the authors read and approved the final manuscript.

\section{Conflicts of Interest}

The authors declare no conflict of interest.

\section{References}

1. United Nations; WHO. The Right to Water. Fact Sheet No. 35; WHO: Geneva, Switzerland, 2010; pp. $1-10$.

2. WHO; UNICEF. Meeting the MDG Drinking Water and Sanitation Target: The Urban and Rural Challenge of the Decade; WHO: Geneva, Switzerland, 2006; pp. 1-10.

3. Gwimbi, P. The microbial quality of drinking water in Manonyane community: Maseru District (Lesotho). Afr. Health Sci. 2011, 11, 474-480.

4. Obi, C.L.; Potgieter, N.; Bessong, P.O.; Matsaung, G. Assessment of the microbial quality of river water sources in rural Venda communities in South Africa. Water SA. 2002, 28, 287-292.

5. UNICEF; WHO. Diarrhoea: Why Children Are Still Dying and What Can Be Done. Available online: http://www.unicef.org/health/files/Final_Diarrhoea_Report_October_2009_final.pdf (accessed on 16 January 2015).

6. Schaefer, M. Water technologies and the environment: Ramping up by scaling down. Technol. Soc. 2008, 30, 415-422.

7. CSIR. Diarrhoea. Available online: http://www.csir.co.za/publications/pdfs/09_pdfsam_ SSNovforweb_diarrhoea.pdf (accessed on 12 January 2015).

8. Gemmell, M.E.; Schmidt, S. Microbiological assessment of river water used for the irrigation of fresh produce in a sub-urban community in Sobantu, South Africa. Food Res. Int. 2012, 47, 300-305.

9. Ibenyassine, K.; Aitmhand, R.; Karamoko, Y.; Cohen, N.; Ennaji, M.M. Use of repetitive DNA sequences to determine the persistence of enteropathogenic Escherichia coli in vegetables and in soil grown in fields treated with contaminated irrigation water. Lett. Appl. Microbiol. 2006, 43, $528-533$.

10. Ebdon, J.; Muniesa, M.; Taylor, H. The application of a recently isolated strain of Bacteroides (GB-124) to identify human sources of faecal pollution in a temperate river catchment. Water Res. 2007, 41, 3683-3690.

11. Prüss-Üstün, A.; Bos, R.; Gore, F.; Bartram, J. Safer Water, Better Health: Costs, Benefits and Sustainability of Interventions to Protect and Promote Health. Geneva: World Health Organization. Available online: http://www.who.int/water_sanitation_health/publications/ safer_water/en/ (accessed on 12 January 2015).

12. Gentry-Shields, J.; Bartram, J. Human health and the water environment: Using the DPSEEA framework to identify the driving forces of disease. Sci. Total Environ. 2014, 468-469, 306-314.

13. WHO. Guidelines for Safe Recreational Water Environments Volume 1: Coastal and Freshwaters; WHO: Geneva, Switzerland, 2003; p. 219. 
14. WHO. Cholera in Zimbabwe. Available online: http://www.who.int/csr/don/2009_06_09/ en/index.html (accessed on 7 January 2015).

15. Kabanda, T.A. A First Synthesis of the Environmental, Biological and Cultural Assets of the Soutpansberg Climate. Available online: http//www.Soutpansberg.com/workshop/synthesis/ climate.htm (accessed on 30 March 2015).

16. APHA. Standard Methods for the Examination of Water and Wastewater, 18th ed.; American Public Health Association: Washington, DC, USA, 1992.

17. DWAF. South African Water Quality Guidelines. Available online: http://www.waternet.co.za/ policy/g_wq.html (accessed on 14 March 2015).

18. WHO. Guidelines for drinking-water quality first addendum to 3rd edition. In Recommendations; WHO: Geneva, Switzerland, 2006; Volume 1.

19. Singh, T.A.; Meetei, N.S.; Meitei, B. Seasonal variation of some physico-chemical characteristics of three major rivers in Imphal, Manipur: A comparative evaluation. Curr. World Environ. 2013, 8, 93-102.

20. Wilbers, G.; Becker, M.; Nga, L.T.; Sebesvari, Z.; Renaud, F.G. Spatial and temporal variability of surface water pollution in the Mekong Delta, Vietnam. Sci. Total Environ. 2014, 485-486, 653-665.

21. Shabalala, A.N.; Combrinck, L.; McCrindle, R. Effect of farming activities on seasonal variation of water quality of Bonsma Dam, KwaZulu-Natal. S. Afr. J. Sci. 2013, 109, 1-7.

22. Anhwange, B.A.; Agbaji, E.B.; Gimba, E.C. Impact assessment of human activities and seasonal variation on River Benue, within Makurdi Metropolis. Int. J. Sci. Technol. 2012, 2, 248-259.

23. Vaishali, P.; Punita, P. Assessment of seasonal variation in water quality of River Mini, at Sindhrot, Vadodara. Int. J. Environ. Sci. 2013, 3, 1424-1436.

24. Odiyo, J.O.; Chimuka, L.; Mamali, M.A.; Fatoki, O.S. Trophic status of Vondo and Albasini Dams; impacts on aquatic ecosystems and drinking water. Int. J. Environ. Sci. Technol. 2012, 9 , 203-211.

25. Edokpayi, J.N.; Odiyo, J.O.; Olasoji, S.O. Assessment of heavy metal contamination of Dzindi River, in Limpopo Province, South Africa. Int. J. Nat. Sci. Res. 2014, 2, 185-194.

26. Lin, J.; Ganesh, A.; Singh, M. Microbial Pathogens in the Umgeni River, South Africa. Available online: http// www.wrc.org.za (accessed on 30 January 2015).

27. Fatoki, O.S.; Muyima, N.Y.O.; Lujiza, N. Situation analysis of water quality in the Umtata River catchment. Water SA 2001, 27, 467-474.

28. Laluraj, C.M.; Gopinath, G. Assessment on seasonal variation of groundwater quality of phreatic aquifers-A river basin system. Environ. Monit. Assess. 2006, 117, 45-57.

29. Ravindra, K.; Ameena; Meenakshi; Monika; Rani; Kaushik, A. Seasonal variations in physico-chemical characteristics of River Yamuna in Haryana and its ecological best-designated use. J. Environ. Monit. 2003. 5, 419-426.

30. Adeyemo, O.K.; Adedokun, O.A.; Yusuf, R.K.; Adeleye, E.A. Seasonal changes in physico-chemical parameter and nutrient load of river sediments in Ibadan city Nigeria. Glob. NEST J. 2008, 10, 326-336.

31. Shrestha, S.; Kazama, F. Assessment of surface water quality using multivariate statistical techniques: A case study of the Fuji river basin, Japan. Environ. Model. Softw. 2007, 22, 464-475. 
32. The Limpopo River Awareness Kit. People and the River. Available online: http://www.limpoporak.com/en/people/socioeconomics+in+the+basin/upstream+vs+downstream. aspx (accessed on 31 March 2015).

33. Retamozo, B.; Shabahang, S.; Johnson, N.; Aprecio, R.M.; Torabinejad, M. Minimum contact time and concentration of sodium hypochlorite required to eliminate Enterococcus faecalis. J. Endod. 2010, 36, 520-523.

34. Chigor, V.N.; Sibanda, T.; Okoh, A.I. Studies on the bacteriological qualities of the Buffalo River and three source water dams along its course in the Eastern Cape Province of South Africa. Environ. Sci. Pollut. Res. 2013, 20, 4125-4136.

35. Sibanda, T.; Chigor, V.N.; Okoh, A.I. Seasonal and spatio-temporal distribution of faecal-indicator bacteria in Tyume River in the Eastern Cape Province, South Africa. Environ. Monit. Assess. 2013, 185, 6579-6590.

36. DWAF. Quality of Domestic Water Supplies Volume 1: Assessment Guide, 2nd ed.; 1998. Available online: http://www.wrc.org.za/Pages/DisplayItem.aspx?ItemID=7114\& FromURL=\%2FPages \%2FDisplayItem.aspx\%3FItemID\%3D7125\%26FromURL\%3D\%252fPage s\%252fDefault.aspx\%253f (accessed on 14 March 2015).

37. WHO. Health Guidelines for the Use of Wastewater in Agriculture and Aquaculture; Technical Report Series No. 778; WHO: Geneva, Switzerland, 1989.

(C) 2015 by the authors; licensee MDPI, Basel, Switzerland. This article is an open access article distributed under the terms and conditions of the Creative Commons Attribution license (http://creativecommons.org/licenses/by/4.0/). 